\title{
COMPARATIVE STUDIES OF SOME COWPEA GENOTYPES AND EVALUATE THE POPULATION ABUNDANCE AND THE INFESTATION BY THE APHIDS IN NEWLY RECLAIMED AREAS AND SALINE WATER UNDER EL-ARISH CONDITIONS. \\ El-Shrief, A. A. M.*; F. M. H. Eid ${ }^{* *}$ and H. A. A. Abul Fadl ** \\ * Field Crops Res. Inst. (FCRI) ). Agric. Res. Center, Giza, Egypt. \\ ** Biological Control Research Department, Plant Protection Research Institute (PPRI). Agric. Res. Center, Giza, Egypt.
}

\begin{abstract}
The present study was conducted to evaluate some morphological characters of some cowpea genotypes under saline water irrigation in newly reclaimed areas, under North Sinai Governorate (El-Arish) conditions as well as the natural infestation with aphid and its hymenopterous parasitoids. Five cowpea genotypes were used; Creamy, Brahma, Buff, Toshki and Chick (Local cultivar). Creamy genotype surpassed the other genotypes of forage yield as well as seeding yield and their attributes followed by Barahma, Buff, Toshki and lastly the Chick (Local) in 2007 and 2008 seasons. The percentage of infestation caused by aphid nymphs varied from (0.49 to $12.7 \%),(0.49$ to $14.6 \%),(0.36$ to $21.8 \%),(0.78$ to $38.5 \%)$ and $(1.22$ to $4.11 \%)$, in the five genotypes, respectively, in the first season (2007). The percentages of infestation varied from $(0.11$ to $13.8 \%),(0.79$ to $3.59 \%),(0.52$ to $20.7 \%)$, (1.55 to $28.9 \%)$ and (3.54 to $35.8 \%)$, respectively, in the second season (2008). On the other hand, the total percentage of infestation among the five tested genotypes ranged between $(0.71$ to $10.8 \%)$ and $(0.67$ to $16.1 \%)$ in the first and the second season, respectively. The average percentages of parasitism caused by the hymenopterous parasitoids on aphid nymphs were 2 to $4 \%$ during the first season 2007 and 4 to $5 \%$ during the second season 2008 , respectively.

Keywords: cowpea, genotypes, saline water, aphid infestation, hymenopterous
\end{abstract} parasitoids.

\section{INTRODUCTION}

The cultivation and reclamation of new reclaimed areas in Sinai is one of Government policy and are considered the top target of the agricultural policy. Cowpea, Vegna siensis (L.), has become the prospective solution to face the shortage of summer forages. This legume forage plays a great role as soil conditioner, besides supplying the soil with organic matter. The value of cowpea lies in its high protein content and ability to tolerate drought. As a legume, cowpea also fixes atmospheric nitrogen, allowing it to grow on and improve poor soils. All parts of cowpea that are used for food are nutritious, providing protein, vitamins, and minerals. Cowpea grain contains about $25 \%$ protein, making it extremely valuable. Cowpea is infested with many pests especially cowpea aphid, Aphis craccivora Koch. (Attia et al., 1987; Metwally, 1998; Nasser et al., 2000 and Rezk et al., 2000). Aphis craccivora causes a virus transmission such as cucumber mosaic virus and papaya ring spot on papaya for some crops in India (Gupta and Tewar, 2007;Abraham et al., 
2007). There are many predators attacking A. craccivora such as Coccinella undecimpunctata L., C. septempunctata L., Cydonia vicina Muls., Harmonia axyridis Pallas which imported from France to control Aphis craccivora, Scymnus interruptus (Coccinellidae), Paedrus alfierii Koch (Staphelinidae: Coleoptera) (El-Desouki et al., 2004; Abou-El-Hagag and Abdel Hafiz,1999; Shantibala et al., 2007; Mandour et al., 2006; El-Arnaouty et al., 2000; Metwally, 1998; El-Defrawi et al., 2000 and Lumbierres et al., 2005); Some Chrysopidae (Neuroptera); Syrphidae (Diptera); Anthocoridae and Geocoridae (Hemiptera) (El-Desouki et al., 2004; El-Defrawi et al., 2000; Abou-El-Hagag and Abdel Hafiz, 1999 ; Mendes et al., 2000). Also, there are many parasitoids_attacking $A$. craccivora such as Lysiphlebus fabarum (Marshall), L. confuses

Tremblay and Eady, L. testaceipes (Cresson), Aphidius matricarae, A. colemani Viereck, A. ervi, Trioxys spp., Ephedrus spp. and Diaeretiella rapae Mc'ntosh (Aphidiidae), (Abdel Samad and Ahmed,2006; Rakhshani et al., 2005; Berta et al., 2002; Abou-Fakher and Kawar,1998 ; Selim et al.,1987) and Aphelinus asychus Walker (Aphelinidae: Hymenoptera) (Monadjemi, 1979). There's still very little information about cowpea behavior under newly reclaimed areas which always suffer of biotic and abiotic stresses. In order to assist the idea, the study was planned to determine some cowpea genotypes adapted in North Sinai areas and resist for saline water with high quantity and quality forage yield. Also to through light on aphid natural infestation and accompanied natural enemies on these cowpea genotypes.

\section{MATERIALS AND METHODS}

The present study was carried out at the Experimental Farm, ELArish Agricultural Research Station, North Sinai in 2007 and 2008 seasons. Seeds of five genetically diverse cowpea genotypes developed in the Forage Research Dept., Field Crop Res. Institute, were sown on May 2007 and 2008 respectively. They are as follows

The studied cowpea genotypes were

\begin{tabular}{|l|l|l|}
\hline Serial no. & Cowpea genotypes & Origin and breeding background \\
\hline 1 & Creamy & Developed by Forage Res. Dep. \\
\hline 2 & Buff & Developed by Forage Res. Dep. \\
\hline 3 & Brahma & Developed by Forage Res. Dep. \\
\hline 4 & Toshki & Developed by Forage Res. Dep. \\
\hline 5 & Chick & Local variety \\
\hline
\end{tabular}

A randomized complete block design with four replications was used. The experimental plot was five rows each, $30 \mathrm{~m}$ long and $50 \mathrm{~cm}$ apart, with a distance of $25 \mathrm{~cm}$ between plants. The recommended agricultural practices and seed inculcation were applied .The soil and irrigation water analysis and the meteorological conditions are shown in Tables 1 and 2. 
Two cuts were made for green forage yield, the $1^{\text {st }}$ one after 60 days of sowing and the $2^{\text {nd }}$ one 50 days after the first cut, and then seeding yield was obtained later.

The studied characters were:-

A: Green forage yield and its characters:

1-Plant height: Measured from soil surface to top leaves.

2-Number of branches/ $\mathrm{m}$. 3-Leaf area $\left(\mathrm{cm}^{2}\right)$

4-Leaf /stem ratio: Weight of dry leaves / weight of dry stem x100.

5-Green yield: fresh plants from each plot were cut and weighed.

6-Dry yield: calculated by multiplying the fresh yield by dry matter percentage.

7- Nodules number/ plant root.

8- Shoot / root ratio.

B: Forage quality:

9-Digestible protein (DP) \%: Nitrogen percentage ( $\mathrm{N} \%$ ) was determined according to A.O.A.C. 1980, the obtained values were multiplied by 6.25 (Tripathi et al., 1971) and (Boltin,1962) to get the crude protein (CP), whereas, digestible protein (DP\%) =0.9596CP-3.55 (Bredon et al.,1963).

10 - Digestible protein yield.: was calculated by multiplying dry yield by DP\%.

C: Seed yield and its character

11- Pod length $(\mathrm{cm})$.

12- Seed number /pod.

13- Pod number/plant.

14- Seed index.

15- Seed yield /plot.

Table (1): Contents and chemical analysis of soil under Al-Arish conditions, North Sinai during 2007 and 2008 seasons.

\begin{tabular}{|c|c|c|c|c|c|c|c|c|c|}
\hline \multicolumn{4}{|c|}{\begin{tabular}{|r|} 
Items \\
\end{tabular}} & \multicolumn{6}{|c|}{ Average of the two seasons } \\
\hline \multicolumn{4}{|c|}{ Sand \% } & \multicolumn{6}{|c|}{95.72} \\
\hline \multicolumn{4}{|c|}{ Silt \% } & \multicolumn{6}{|c|}{2.31} \\
\hline & \multicolumn{6}{|c|}{1.72} \\
\hline \multicolumn{4}{|c|}{ Soil texture } & \multicolumn{6}{|c|}{ Sand } \\
\hline \multicolumn{10}{|c|}{ Chemical analysis (soluble ions in $1: 5$ extract) } \\
\hline \multicolumn{4}{|c|}{ Total N (ppm) } & \multicolumn{6}{|c|}{12.5} \\
\hline \multicolumn{4}{|c|}{ Total P (ppm) } & \multicolumn{6}{|c|}{46.5} \\
\hline \multicolumn{4}{|c|}{ Total K (ppm) } & \multicolumn{6}{|c|}{91.5} \\
\hline \multicolumn{4}{|c|}{$\mathrm{Ca}^{++} \mathrm{meq} / 1$} & \multicolumn{6}{|c|}{2.3} \\
\hline \multicolumn{4}{|c|}{$\mathrm{Mg}^{++} \mathrm{meq} / 1$} & \multicolumn{6}{|c|}{0.9} \\
\hline \multicolumn{4}{|c|}{$\mathrm{Na}^{++} \mathrm{meq} / 1$} & \multicolumn{6}{|c|}{2.37} \\
\hline \multicolumn{4}{|c|}{$\mathrm{K}^{+} \mathrm{meq} / 1$} & \multicolumn{6}{|c|}{0.15} \\
\hline \multicolumn{4}{|c|}{$\mathrm{Cl}^{-} \mathrm{meq} / 1$} & \multicolumn{6}{|c|}{4.4} \\
\hline \multicolumn{4}{|c|}{$\mathrm{CO}_{3}-\mathrm{meq} / 1$} & \multicolumn{6}{|c|}{----} \\
\hline \multicolumn{4}{|c|}{$\mathrm{HCO}_{3}-\mathrm{meq} / 1$} & \multicolumn{6}{|c|}{1.4} \\
\hline \multicolumn{4}{|c|}{$\mathrm{SO}_{4}^{--} \mathrm{meq} / 1$} & & & & 1.96 & & \\
\hline $\mathrm{ECe}(\mathrm{c}$ & m-1) in(1 & 5ext.) & & & & & 0.69 & & \\
\hline $\mathrm{PH}$ in & $1: 5 e x t)$. & & & & & & 7.55 & & \\
\hline Organ & c matter\% & & & & & & 0.06 & & \\
\hline $\mathrm{CaCO}$ & & & & & & & 8.05 & & \\
\hline & & & & & & able io & & & \\
\hline $\mathrm{PH}$ & Ece dsm & & Cati & & & & & & \\
\hline & & $\mathrm{Ca}^{++}$ & $\mathrm{Mg}^{++}$ & $\mathrm{Na}^{+}$ & $\mathrm{K}^{+}$ & $\mathrm{Cl}^{-}$ & $\mathrm{HCO}_{3}$ & $\mathrm{CO}_{3}^{-}$ & $\mathrm{SO}_{4}^{--}$ \\
\hline 7.5 & 7.54 & 15.4 & 14.6 & 45.2 & 0.2 & 47.5 & 2.00 & -- & 25.9 \\
\hline
\end{tabular}


Table (2):Average agroclimatological data for summer seasons(2007and 2008) North Sinai Governorate.

\begin{tabular}{|l|c|c|c|c|c|}
\hline \multirow{2}{*}{ Month } & \multicolumn{2}{|c|}{ Temperature } & \multirow{2}{*}{ R.H } & \multirow{2}{*}{ R.F } & \multirow{2}{*}{ E.pan } \\
\cline { 2 - 3 } & Max. & Min & & & \\
\hline April & 25.8 & 13.9 & 79 & 0.0 & 6.0 \\
\hline May & 27.8 & 15.1 & 80 & 0.0 & 7.1 \\
\hline June & 30.1 & 18.7 & 84 & 0.0 & 8.2 \\
\hline July & 32.7 & 21.6 & 84 & 0.0 & 8.2 \\
\hline August & 32.9 & 23.0 & 75 & 0.0 & 7.7 \\
\hline September & 31.6 & 20.4 & 82 & 0.0 & 6.0 \\
\hline October & 28.7 & 17.2 & 80 & 0.0 & 4.9 \\
\hline
\end{tabular}

Where: T. $\max$, T. $\min .=$ maximum and minimum temp. ${ }^{\circ} \mathrm{C} ; \mathbf{R} . \mathbf{H} .=$ relative humidity $(\%)$ R.F. = rain full $(\mathrm{mm} / \mathrm{month})$ and $E$. pan= evaporation pan $(\mathrm{mm} / \mathrm{day})$.

D- Percentage of infestation with Aphis craccivora Koch. and the population abundance in the field.

Twenty-five plants of each variety were randomly selected weekly. The number of infested leaflets with aphid was counted per plant. The number of infested leaflets related to the whole number of leaflets in the sample was estimated for each variety. The average percentage of infestation was calculated by applying the following formula:-

$$
\text { Infestation\% }=\frac{\text { No. of infested leaflets }}{- \text { Total no. of examined leaflets. }}
$$

The selected plants used for estimating the percentage of infestation was used in calculating the number of aphids. The number of aphids was counted per leaflet/ inch 2 .

\section{E- Percentage of parasitism:}

One hundred infested leaflets were collected weekly from each cowpea variety. The collected samples were kept in paper bags and were transferred to the laboratory. The percentage of parasitism of cowpea aphids was calculated. Aphids obtained from infested leaflets were chosen to evaluate the percentage of parasitism by dissecting under a stereomicroscope. The average percentage of parasitism was then calculated by applying the following formula:-

$$
\text { Parasitism\% }=\frac{\text { No. of parasitised nymphs }}{\text { Total no. of examined nymphs }} \times 100
$$

\section{F- Common recorded natural enemies:}

The predatory species associated with cowpea plants are recorded in the field. The collection of the infested leaflets is made. Each aphid mummy was kept in a glass vial until emergence of parasitoids. Emerged parasitoid species were collected and identified in Biological Control Research Department, PPRI, ARC, Giza. 


\section{Statistical analysis:}

Data were subjected to analysis of variance (ANOVA) and the means were compared by L. S. D. test at 0.05 level according to Sendecor and Cochran (1968). The genotypic $\mathrm{O}^{-2} \mathrm{~g}$ and phenotypic $\mathrm{O}^{-2} \mathrm{p}$ variance, heritability in broad sense $\mathrm{H}^{2}$ and genotypic gcv and phenotypic pcv co-efficient of variability were estimated for combined data (AL-Jibouri et al., 1958; Hanson and Robinson, 1956; Burton, 1952).

\section{RESULTS AND DISCUSSION}

\section{A-Green forage yield and its attributes:}

The average of plant height, no. of branches, leaf area, leaf stem ratio, green yield and dry yield of the tested cowpea genotypes for the first cut over the two seasons and their average are presented in Table (3). The obtained data show that indicated Creamy genotype surpassed all other genotypes in forage yield and its, attributes followed by Buff, Brahma, Toshki and lastly the Chick over two seasons. The plant height measured in the 5 cowpea genotypes was $53.6,45.5,43.2,30.5$ and $28.5 \mathrm{~cm}$, respectively. The number of branches plant in both seasons, was the highest in Creamy followed by the other four genotypes. Creamy genotype surpassed all other genotypes concerning leaf area, leaf/ stem ratio, forage yield, dry yield, and digest. Pro. Creamy and Buff genotypes had the same no. of nodules/ root (10) followed by the other three genotypes ( 8,7 and 4 ) nodules, respectively. No. of shoot/ root ratio was the highest in Chick genotype $(2.763)$ followed by Toshki (2.170) then Baharma (1.854) and Buff (1.756), while Creamy genotype was last one (1.293). Escechie and Redriguez (1998), reported that plant growth characteristics were mainly differed due to cultivars, such deferring could genetically explained. According to the cuts, (Table 4) illustrates the superiority of Creamy genotype compared to other cowpea genotypes followed by Buff, Brahma, Toshki and Chick in all studied forage yield characters. It is obviously clear that both Creamy and Buff genotypes showed highly significant differences in all herbage traits in the second cut during the two seasons and their average compared to the studied cowpea characters and these genotypes might play a great role concerning cowpea salinity tolerance programs.

\section{Number of nodules/ plant and shoot/ root ratio:}

It is obviously clear that Creamy genotype plants had more active nodules than other studied genotypes capable to serve high $(\mathrm{N})$ fixation supplying the plant and the soil with more $(\mathrm{N})$ and more organic matter of the harvesting. In this respect, Daterao et al. (1994) and Mohamed (1999) found that inoculation of all legumes enhanced nodulation $\mathrm{N}$-fixation, nitrogen content and the activation in the root nodule numbers increasing fixed $\mathrm{N}$ and roots with more active nodule numbers due to ascribed increase in growth of plant root with $\mathrm{N}$ fertilization enhancing absorption of the nutrient. Regarding shoot/ root ratio, it is interesting to mention that root development is close to plant ability to absorb more water and hence is great significant in salt water irrigation resistance. Plants showed more resistance, but must be connected 
by the increment root to shoot ratio, and /or lowest value of shoot/ root which seemed to be clear in the Creamy genotype (1.322), followed by Buff (1.958), Brahma (2.009), Toshki (2.209) and Chick (2.882) these results were also in harmony with those obtained by Ashraf et. al. (1987), and Lugg et. al. (1985).

Table (3): Mean performance of the studied characters in 5 cowpea genotypes under salinity conditions, North Sinai, $1^{\text {st }}$ cut in $1^{\text {st }}, 2^{\text {nd }}$ seasons and their average.

\begin{tabular}{|c|c|c|c|c|c|c|c|c|c|c|c|}
\hline 16 & $\begin{array}{c}\text { Plant } \\
\text { Height } \\
(\mathrm{cm})\end{array}$ & $\begin{array}{c}\text { Branches } \\
\text { /Plant } \\
\text { (No) }\end{array}$ & $\begin{array}{l}\text { Leaf } \\
\text { Area }\end{array}$ & $\begin{array}{l}\text { Leaf } / \\
\text { stem }\end{array}$ & $\begin{array}{c}\text { Green } \\
\text { yield }\end{array}$ & $\begin{array}{c}\text { Dry } \\
\text { yield }\end{array}$ & $\left|\begin{array}{c}\text { Root } \\
\text { length }\end{array}\right|$ & $\begin{array}{l}\text { No } \\
\text { no }\end{array}$ & $\begin{array}{c}\text { Sh } \\
\text { rc }\end{array}$ & Di & $\begin{array}{l}\text { Dig. } \\
\text { pro.yd }\end{array}$ \\
\hline \multicolumn{12}{|c|}{$1^{\text {st }}$ cut in the $1^{\text {st }}$ season } \\
\hline Creamy & 0.00 & 00 & 7.63 & 1.10 & 7.55 & 1.027 & 13.50 & 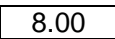 & 93 & 91 & 29 \\
\hline Buff & 50 & 75 & & 0.83 & & & & & & & \\
\hline arahma & .5 & 25 & & & & & & & & & \\
\hline Toshki & 29.75 & 11.00 & & 0. & 54 & & & & & & \\
\hline Chick & 24.00 & 10.75 & & & & & & & & & \\
\hline L.S.D. & 155 & 3.209 & & 0.11 & 0.902 & 0.123 & 0.745 & & & & \\
\hline \multicolumn{12}{|c|}{$1^{\text {st }}$ cut in the $2^{\text {nd }}$ season } \\
\hline Crear & 3.60 & 18.50 & 30 & 1.30 & 8.30 & 1.170 & 16.50 & & 59 & & 333 \\
\hline Buff & 45.50 & 15.30 & & 0 . & & & & & & & 325 \\
\hline Barahma & 43.20 & 13.20 & & & & & & & & & 98 \\
\hline Toshki & 30.50 & 12.50 & & 0 . & 20 & & & & & & 31 \\
\hline Chick & .50 & 11.40 & & 0.63 & 30 & 0. & & & & & 33 \\
\hline & 769 & 3.386 & 5.034 & 0.279 & 1.112 & 0.149 & 2.141 & 2.280 & & & 77 \\
\hline \multicolumn{12}{|c|}{ Average of $1^{\text {st }}$ cut in both $1^{\text {st }}$ and $2^{\text {nd }}$ seasons } \\
\hline $1 y$ & 80 & 17.25 & & 1.2 & & 1. & & & & & 19 \\
\hline Buff & 44.00 & 15.03 & 72. & 0.840 & 60 & 0.954 & & 0 & 26 & & 16.208 \\
\hline Barahm & 43.60 & 12.73 & & 0.765 & 7.570 & 0.892 & & & & & 14.201 \\
\hline Toshki & 30.13 & 11.75 & & 0.675 & 4.870 & 0.658 & 11.60 & 5.00 & 2.175 & 13.076 & 10.265 \\
\hline 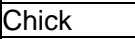 & 26.25 & 11.08 & & 0.605 & 3.650 & 0.476 & & & & & 6.943 \\
\hline .S.D. & 3.663 & 26.34 & 3.856 & 1.880 & 0.618 & 0.683 & 1.20 & 1.14 & 0.283 & 1.701 & 1.338 \\
\hline
\end{tabular}

\section{B- Forage quality:}

The highest recorded values of protein yield \% (Table 4) were obtained from Creamy genotype followed by, Brahma, Buff, Toshki and the Chick genotype (52.934, 40.330, 34.193, 28.177 and 14.557) in their average over the two seasons. Data in Table (3) illustrates that Creamy genotype gave the highest value of digestible protein in the first cut through the two years and their average (18.129, 21.333 and 19.731), followed by Brahma (15.091, 17.325 and 16.208), respectively, (Table 3 and 4). The same trend was also observed in the $2^{\text {nd }}$ cut in both seasons (Table 4). Slight differences observed between Buff and Brahma genotypes. For digestible protein yield $\mathrm{kg} /$ fed., the superiority were revealed by Creamy and Brahma genotypes (Table 4). Mcharsie (1994) working on cowpea cvs. reported that cowpea genotypes differed in both chemical content, but the differences were not significant. 
J. Agric. Sci. Mansoura Univ., 34 (3), March, 2009

$\varepsilon$ 


\section{C-Seed yield characters:}

The results of seed and its components (Tables 3 and 4) exhibited highly significant differences in all studied seed yield characters. Creamy genotype surpassed all the other cowpea genotypes in pod length, seed no.

/pod, seed index and seed yield /plot.

The differences between cowpea genotypes were also reported by Gad EL-Hak et.al (1988), Mohamed (1999) and Zayed and Mohamed (2003) proved that seed/pod considered as varietals character.

\section{Habitability and genetic:}

Table (5) illustrates the phenotypic (p.c.v.), genotypic (g.c.v.) coefficient of variability and heritability in broad sense $\left(\mathrm{H}^{2}\right)$ for the combined analysis of the cowpea genotypes. Regarding characters, seed index, pod no., /plant, seed no., /pod and seed yield / plant. Table (5) exhibited highest values of $\left(\mathrm{H}^{2}\right)(86.70,69.60,54.43$ and $50.00 \%)$, respectively, indicating that these characters could improve phenotypic selection. Also, the data of p.c.v., and g.c.v., reveal high estimates of genotypic variance. The results of these traits were in agreement with that obtained by Hussein and Farghali (1998) and Zayed and Mohamed (2003). Sobba and vahaba Abdul (1998) also were in harmony with the obtained results given by Aggarwal (1987), Kumar and Sangwam (2003) and Peksen and Artik (2004).

On the other hand, the inferior values of broad sense heritability were revealed by green yield and pod length (22.50 and 26.5), respectively, as regards the previous traits, it is interesting to maintain that low values of $\left(\mathrm{H}_{2}\right)$ indicating remarkable environmental effects and the varietals effects, the similar trends were reported by Zayed and Mohamed(2003) and Abo Baker et al.(1983). Traits exhibited genotypic and phenotypic coefficient with slight repugnancy between them for the investigated traits reoffered highly genotypic variance.

Table (5): the phenotypic (p.c.v.), genotypic (g.c.v.) coefficient of variability and heritability in broad sense (H2) for the combined analysis of the cowpea genotypes .

\begin{tabular}{|l|c|c|c|c|c|}
\hline \multicolumn{1}{|c|}{ Characters } & $\mathbf{O}^{-2} \mathbf{p}$ & $\mathbf{O}^{-2} \mathbf{g}$ & $\mathbf{H}^{\mathbf{2}}$ & $\mathbf{p . c . v}$ & $\mathbf{g . c . v}$ \\
\hline 1- Pod length cm & 1.52 & 0.64 & 42.11 & 6.40 & 3.80 \\
\hline 2- Seed no./pod & 1.58 & 0.86 & 54.43 & 13.60 & 10.20 \\
\hline 3-Pod no. / plant & 0.158 & 0.11 & 69.60 & 24.50 & 19.30 \\
\hline 4- Seed index & 18.80 & 16.3 & 86.70 & 20.70 & 24.80 \\
\hline 5-Seed yield/plant & 0.36 & 0.180 & 50.10 & 18.60 & 19.30 \\
\hline 6-Green yield & 0.58 & 0.16 & 27.59 & 11.70 & 13.80 \\
\hline
\end{tabular}

\section{D- Percentage of infestation and the population abundance:}

Percentages of infestation with aphid, Aphis craccivora Koch. and the population abundance on leaflets of the five tested cowpea genotypes for the successive sampling are shown in Table $(6,7$ \& 8).

For 2007 season, the percentage of infestation in the Creamy genotype ranged between $0.49 \%$ in the fourth week of July to $12.7 \%$ in the fifth week of July, with an average of $1.66 \%$. The total number of aphid ranged between 14 
and 814 aphids. Population with aphid demonstrated two peaks. The $1^{\text {st }}$ peak (65 aphids) occurred on July 16 and the $2^{\text {nd }}$ peak (814 aphids) on July 30 . In the Brahma genotype, the percentage of infestation ranged between $0.49 \%$ in the second week of August and $14.6 \%$ in the fourth week of July, with an average of $1.99 \%$. The total number of aphid ranged between 33 and 1508 aphids. Population with aphid demonstrated two peaks. The $1^{\text {st }}$ peak (39 aphids) occurred on September 17 and the $2^{\text {nd }}$ peak (1508 aphids) on July 23. In the Buff genotype, the percentage of infestation ranged between $0.36 \%$ in the second week of August and $21.8 \%$ in the fifth week of July, with an average of $2.87 \%$. The total number of aphids ranged between 22 and 2496 aphids. Population with aphid demonstrated three peaks. The $1^{\text {st }}$ peak (780 aphids) occurred on July 16 , the $2^{\text {nd }}$ peak (2496 aphids) on July 30 and the $3^{\text {rd }}$ peak on September 17. In the Toshki genotype, the percentage of infestation ranged between $0.78 \%$ in the third week of September and $38.5 \%$ in the third week of July, with an average of $2.22 \%$. The total number of aphid ranged between 27 and 1222 aphids. Population with aphid demonstrated three peaks. The $1^{\text {st }}$ peak (152 aphids) occurred on July 9 , the $2^{\text {nd }}$ peak (1222 aphids) on July 23 and the $3^{\text {rd }}$ peak (27 aphids) on September 17.In variety Local (Chick) genotype, the percentage of infestation ranged between 1.22 in the second week of July and $4.11 \%$ in the fourth week of July, with an average of $2.06 \%$. The total number of aphid ranged between 30 and 414 aphids. Population with aphid demonstrated two peaks. The $1^{\text {st }}$ peak (414 aphids) occurred on July 23 and the $2^{\text {nd }}$ peak (300 individual) on August 13 (Table 6 \& 7).

On the other hand, the average percentage of infestation in the entire treatment in 2007 season ranged between $0.71 \%$ in the fourth week of September and $10.8 \%$ in the fifth week of July, with an average of $0.50 \%$. The total number of aphid ranged between 121 and 8228 aphids. Population with aphid demonstrated three peaks. The $1^{\text {st }}$ peak (8228 aphids) occurred on July 30 , the $2^{\text {nd }}$ peak (380 aphids) on August 13 and the $3^{\text {rd }}$ peak (224 aphids) on September 17 (Table $6 \&$ 7).

In 2008 season, the percentage of infestation in the genotype Creamy ranged between $0.11 \%$ in the fourth week of July and $13.8 \%$ in the third week of August, with an average of $2.92 \%$. The total number of aphid ranged between 208 and 4510 aphids. Population with aphid demonstrated two peaks. The $1^{\text {st }}$ peak (2516 aphids) occurred on July 30 and the $2^{\text {nd }}$ peak (4510 aphids) on August 20. In the genotype Barahma, the percentage of infestation ranged between $0.79 \%$ in the second week of August and $3.59 \%$ in the $3^{\text {rd }}$ week of August, with an average of $1.73 \%$. The total number of aphid ranged between 66 and 720 aphids. Population with aphid demonstrated four peaks. The $1^{\text {st }}$ peak (66 aphids) occurred on July 2 , the $2^{\text {nd }}$ peak (380 aphids) on July 16, the $3^{\text {rd }}$ peak (720 aphids) on August 6 and the $4^{\text {th }}$ peak (600 aphids) on August 20. In the genotype Buff, the percentage of infestation ranged between $0.52 \%$ in the second week of August and $20.7 \%$ in the first week of August, with an average of $3.88 \%$. The total number of aphid ranged between 44 and 10004 aphids. Population with aphid demonstrated four peaks. The $1^{\text {st }}$ peak (72 aphids) occurred on July 2 , the $2^{\text {nd }}$ peak (9724 aphids) on July 23, the $3^{\text {rd }}$ peak (10004 aphids) on August 6, and 
the $4^{\text {th }}$ peak (360 aphids) on August 27 . In the genotype Toshki, the percentage of infestation ranged between $1.55 \%$ in the first week of July and $28.9 \%$ in the first week of August, with an average of $10.31 \%$. The total number of aphid ranged between 98 and 13818 aphids. Population with aphid demonstrated two peaks. The $1^{\text {st }}$ peak (98 aphids) occurred on July 2 and the $2^{\text {nd }}$ peak (13813 aphids) on August 6 . In the genotype Local (Chick), the percentage of infestation ranged between $3.54 \%$ in the first week of September and $35.8 \%$ in the fourth week of July, with an average of $10.61 \%$. The total number of aphid ranged between 851 and 23750 aphids. Population with aphid demonstrated three peaks. The $1^{\text {st }}$ peak (23750 aphids) occurred on July 23 , the $2^{\text {nd }}$ peak (4836 aphids) on August 20 and the ${ }^{\text {rd }}$ peak (1798 aphids) on September 3, (Table 6 \& 8).

On the other hand the average percentage of the infestation in the entire treatment in 2008 season ranged between $0.67 \%$ in the $1^{\text {st }}$ week of September and $16.1 \%$ in the fourth week of July, with an average of $6.38 \%$. The total number of aphid ranged between 989 and 42800 aphids. Population with aphid demonstrated four peaks. The $1^{\text {st }}$ peak (1456 aphids) occurred on July 2; the $2^{\text {nd }}$ peak (42800_aphids) on July 23 , the $3^{\text {rd }}$ peak (10138 aphids) on August 20 and the $4^{\text {th }}$ peak (1488 aphids) on September 3, (Table 6 \& 8).

Statistical analysis showed that, in the first season 2007, there is no significant difference in percentage of infestation and population abundance between the varieties and the two season in the entire treatment. But in the second season 2008, showed that there are significant difference in percentage of infestation and population abundance between the varieties (Creamy, Brahma and Buff ) and the varieties (Toshki and Chick ) while, in the entire treatment, the second year 2008 has high significant difference (Tables 6, 7 \& 8 ).

\section{E- Percentage of parasitism:}

In the two seasons, the percentage of parasitism was very low. The average percentages of parasitism were 2 to $4 \%$ during the first season 2007 and 4 to $5 \%$ during the second season 2008, respectively.

\section{Hymenopterous parasitoids attacking $A$. craccivora in cowpea genotypes:-}

Four parasitoid species were recorded from $A$. cracivora. The secured parasitoid species from two successive seasons, 2007 and 2008 were; Aphelinus sp. (Aphelinidae), Aphidius colemani, A. matricariae and Lysiphlebus fabarum (Aphidiidae: Hymenoptera).

Monadjemi (1979), Selim et al., (1987), Rezk et al.,(2000) and Abdelsamad and Ahmed (2006) also recorded these parasitoids on the cowpea aphid.

\section{F- Common predators recorded in cowpea fields:-}

Field observation showed that the predator Chrysoperla carnea Steph. (Chrysopidae: Neuroptera) and some coccinellids; Coccinella undecimpunctata and Scymnus spp. (Coccinellidae: Coleoptera) feeding on the nymphs of cowpea aphid during the two seasons 2007\& 2008. Metwally (1998), Abou-El-Hagag and Abdel-Hafiz (1999), Nasser et al., (2000) and ElDesouki et al., (2004) also recorded the same predator species in cowpea fields. 
Table (6): Percentages of infestation by $A$. craccivora in cowpea in the varieties, El-Arish, North Sinai .

\begin{tabular}{|c|c|c|c|c|c|c|c|c|c|c|c|c|}
\hline \multirow{3}{*}{$\begin{array}{c}\text { Sampling } \\
\text { date }\end{array}$} & \multicolumn{12}{|c|}{$\%$ Infestation } \\
\hline & \multicolumn{6}{|c|}{ Season 2007} & \multicolumn{6}{|c|}{ Season 2008} \\
\hline & Creamy & Brahma & Buff & \begin{tabular}{|c|}
$\begin{array}{c}\text { Tosh- } \\
\text { ki }\end{array}$ \\
\end{tabular} & Chick & Treat & Creamy & Brahma & Buff & \begin{tabular}{|c|}
$\begin{array}{c}\text { Tosh- } \\
\text { ki }\end{array}$ \\
\end{tabular} & Chick & Treat \\
\hline $18 / 6$ & & & & & & & 0 & 0 & 0 & 0 & 0 & 0 \\
\hline $25 / 6$ & & & & & & & 0 & 0 & 0 & 0 & 0 & 0 \\
\hline $2 / 7$ & & & & & & & 0 & 1.34 & 1.16 & 1.55 & 8.04 & 2.41 \\
\hline $9 / 7$ & 1.14 & 0 & 4.8 & \begin{tabular}{|l|}
3.81 \\
\end{tabular} & 1.22 & 2.16 & 0 & 0 & 0.96 & 0 & 7.86 & 1.74 \\
\hline $16 / 7$ & 2.16 & 4.47 & 11.2 & 38.5 & 2.72 & 4.72 & 4.49 & 3.52 & 3.18 & 7.33 & 20.4 & 8.53 \\
\hline $23 / 7$ & 0.49 & 14.6 & 3.85 & 9.33 & 4.11 & 6.4 & 0.11 & 2.33 & 19.3 & 12.9 & 35.8 & 16.1 \\
\hline $30 / 7$ & 12.7 & 6.81 & 21.8 & 10 & 3.69 & 10.8 & 6.17 & 1.5 & 7.85 & 24.7 & 22.5 & 13.1 \\
\hline $6 / 8$ & 1.76 & 1.94 & 1.25 & \begin{tabular}{|l|}
1.96 \\
\end{tabular} & 2.86 & 1.93 & 1.26 & 3.23 & 20.7 & 28.9 & 4.71 & 12.5 \\
\hline $13 / 8$ & 0 & 0.49 & 0.36 & 0 & 3.33 & 0.75 & 1.44 & 0.79 & 0.52 & 20.3 & 4.71 & 6.02 \\
\hline $20 / 8$ & 0 & 0 & 0 & 0 & 0 & 0 & 13.8 & 3.59 & 0 & 2.73 & 19.6 & 7.98 \\
\hline $27 / 8$ & 0 & 0 & 0 & 0 & 0 & 0 & 1.37 & 1.47 & 3.06 & 0 & 0 & 0.68 \\
\hline $3 / 9$ & 0 & 0 & 0 & 0 & 0 & 0 & 0 & 0 & 0 & 0 & 3.54 & 0.67 \\
\hline 109 & 0 & 0 & 0 & 0 & 0 & 0 & 0 & 0 & 0 & 0 & 0 & 0 \\
\hline $17 / 9$ & 1.15 & 0.72 & 1.64 & \begin{tabular}{|l|}
0.78 \\
\end{tabular} & 0 & 0.85 & & & & & & \\
\hline $24 / 9$ & 1.9 & 0.93 & 0 & 0 & 0 & 0.71 & & & & & & \\
\hline Mean & $\begin{array}{c}A \\
1.66 \\
\end{array}$ & $\begin{array}{c}A \\
1.99 \\
\end{array}$ & $\begin{array}{c}A \\
2.87 \\
\end{array}$ & $\begin{array}{c}\mathrm{A} \\
2.22 \\
\end{array}$ & $\begin{array}{c}\mathrm{A} \\
2.06 \\
\end{array}$ & $\begin{array}{c}B \\
0.50\end{array}$ & $\begin{array}{c}B \\
2.92 \\
\end{array}$ & $\begin{array}{c}B \\
1.73 \\
\end{array}$ & $\begin{array}{c}\text { B } \\
3.88 \\
\end{array}$ & $\begin{array}{c}A \\
10.31 \\
\end{array}$ & $\begin{array}{c}A \\
10.61 \\
\end{array}$ & $\begin{array}{c}A \\
6.38 \\
\end{array}$ \\
\hline $\begin{array}{c}\text { L.S.D. } \\
0.05 \\
\end{array}$ & \multicolumn{5}{|c|}{1.4014} & 1.3098 & \multicolumn{5}{|c|}{3.6307} & 1.3098 \\
\hline
\end{tabular}

Table (7): Population abundance of $\boldsymbol{A}$. craccivora on different cowpea varieties (25 plants examined per sample) during 2007 season in El- Arish conditions.

\begin{tabular}{|c|c|c|c|c|c|c|c|}
\hline \multirow{3}{*}{$\begin{array}{l}\text { Sampling } \\
\text { date }\end{array}$} & \multicolumn{7}{|c|}{ No. of A craccivora on cowpea varieties / sample in season 2007} \\
\hline & Creamy & Brahma & Buff & Toshki & Chick & $\angle$ & Treat. \\
\hline & $\begin{array}{l}\text { Total no. of } \\
\text { aphid }\end{array}$ & $\begin{array}{l}\text { Total no. of } \\
\text { aphid }\end{array}$ & $\begin{array}{c}\text { Total no. of } \\
\text { aphid }\end{array}$ & $\begin{array}{c}\text { Total no. of } \\
\text { aphid }\end{array}$ & $\begin{array}{c}\text { Total no. of } \\
\text { aphid }\end{array}$ & 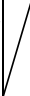 & $\begin{array}{c}\text { Total no. } \\
\text { of } \\
\text { aphid }\end{array}$ \\
\hline $18 / 6$ & 0 & 0 & 0 & 0 & 0 & 7 & 0 \\
\hline $25 / 6$ & 0 & 0 & 0 & 0 & 0 & 7 & 0 \\
\hline $2 / 7$ & 0 & 0 & 0 & 0 & 0 & 7 & 0 \\
\hline $9 / 7$ & 30 & 0 & 264 & $152 *$ & 30 & $Z$ & 572 \\
\hline $16 / 7$ & 65 * & 240 & 780 * & 55 & 98 & 7 & 1475 \\
\hline $23 / 7$ & 14 & 1508 * & 345 & 1222 * & 414 * & $Z$ & 4958 \\
\hline $30 / 7$ & 814 * & 506 & 2496 * & 840 & 330 & $Z$ & 8228 * \\
\hline $6 / 8$ & 105 & 112 & 65 & 190 & 160 & 7 & 819 \\
\hline $13 / 8$ & 0 & 33 & 22 & 0 & 300 * & 7 & 380 * \\
\hline $20 / 8$ & 0 & 0 & 0 & 0 & 0 & 7 & 0 \\
\hline $27 / 8$ & 0 & 0 & 0 & 0 & 0 & 7 & 0 \\
\hline $3 / 9$ & 0 & 0 & 0 & 0 & 0 & 7 & 0 \\
\hline $10 / 9$ & 0 & 0 & 0 & 0 & 0 & 7 & 0 \\
\hline $17 / 9$ & 60 & 39 * & 60 * & $27^{*}$ & 0 & $Z$ & $224 \quad$ * \\
\hline $24 / 9$ & 152 & 36 & 0 & 0 & 0 & V & 121 \\
\hline Total & 1240 & 2474 & 4032 & 2486 & 1332 & $Z$ & 16697 \\
\hline Mean \pm S.E & $\begin{array}{c}\mathrm{A} \\
103.33 \pm 66.15 \\
\end{array}$ & $\begin{array}{c}A \\
206.17 \pm 125.95 \\
\end{array}$ & $\begin{array}{c}\text { A } \\
336 \pm 207.45\end{array}$ & $\begin{array}{c}\mathrm{A} \\
207.17 \pm 115.04 \\
\end{array}$ & $\begin{array}{c}\mathrm{A} \\
111 \pm 44.26 \\
\end{array}$ & 7 & $\begin{array}{c}B \\
2.0512\end{array}$ \\
\hline $\begin{array}{|ll|}\text { L.S.D. } & 0.05 \\
\end{array}$ & & & 268.6 & & & V & 1.3098 \\
\hline
\end{tabular}


Table ( 8 ): Population abundance of $A$. craccivora on different cowpea varieties(25 plants examined per sample) during 2008 season in El- Arish conditions

\begin{tabular}{|c|c|c|c|c|c|c|c|}
\hline \multirow{3}{*}{$\begin{array}{l}\text { Sampling } \\
\text { date }\end{array}$} & \multicolumn{7}{|c|}{ No. of A craccivora on cowpea varieties / sample in season 2008} \\
\hline & Creamy & Brahma & Buff & Toshki & Chick & ד & Treat \\
\hline & $\begin{array}{c}\text { Total no. of } \\
\text { aphid }\end{array}$ & $\begin{array}{l}\text { Total no. } \\
\text { of aphid }\end{array}$ & $\begin{array}{l}\text { Total no. of } \\
\text { aphid }\end{array}$ & $\begin{array}{c}\text { Total no. of } \\
\text { aphid }\end{array}$ & \begin{tabular}{|c|}
$\begin{array}{c}\text { Total no. of } \\
\text { aphid }\end{array}$ \\
\end{tabular} & 7 & $\begin{array}{c}\text { Total no. of } \\
\text { aphid }\end{array}$ \\
\hline $18 / 6$ & 0 & 0 & 0 & 0 & 0 & 7 & 0 \\
\hline $25 / 6$ & 0 & 0 & 0 & 0 & 0 & 7 & 0 \\
\hline $2 / 7$ & 0 & 66 * & 72 * & 98 * & 851 & 7 & 1456 * \\
\hline $9 / 7$ & 0 & 0 & 45 & 0 & 1131 & 7 & 1012 \\
\hline $16 / 7$ & 594 & 380 * & 504 & 1612 & 7052 & 4 & 12936 \\
\hline $23 / 7$ & 640 & 342 & 9724 * & 5460 & 23750 * & $y$ & 42800 * \\
\hline $30 / 7$ & 2516 * & 204 & 2475 & 11880 & 10492 & 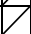 & 32781 \\
\hline $6 / 8$ & 266 & 720 * & 10004 * & 13818 * & 1118 & 7 & 31020 \\
\hline $13 / 8$ & 315 & 72 & 44 & 7917 & 1032 & 7 & 10027 \\
\hline $20 / 8$ & 4510 * & 600 * & 0 & 285 & 4836 * & 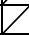 & 10138 * \\
\hline $27 / 8$ & 208 & 140 & $360^{*}$ & 0 & 0 & 7 & 989 \\
\hline $3 / 9$ & 0 & 0 & 0 & 0 & $1798^{*}$ & 7 & $1488^{*}$ \\
\hline $10 / 9$ & 0 & 0 & 0 & 0 & 0 & 7 & 0 \\
\hline $17 / 9$ & - & - & - & - & - & 4 & - \\
\hline $24 / 9$ & - & - & - & - & - & 7 & - \\
\hline Total & 9049 & 2524 & 23228 & 41070 & 142060 & 7 & \\
\hline Mean $\pm S . E$ & $\begin{array}{c}\mathrm{B} \\
904.9 \pm 464.97\end{array}$ & \begin{tabular}{|c|} 
B \\
$257.78 \pm 84.47$
\end{tabular} & $\begin{array}{c}\mathrm{B} \\
2322.8 \pm 1278.89\end{array}$ & $\begin{array}{c}\text { A B } \\
4107 \pm 1695.02\end{array}$ & $\begin{array}{c}A \\
5206 \pm 2318.50\end{array}$ & 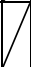 & $\begin{array}{c}A \\
6.3794\end{array}$ \\
\hline \begin{tabular}{|ll} 
L.S.D. & 0.05 \\
\end{tabular} & & & 3613.7 & & & & 1.3098 \\
\hline
\end{tabular}

${ }^{*}=$ the peak

Means with the same letter are insignificantly different.

\section{REFERENCES}

Abdel-Samad, S. S. M. and M. A. Ahmed (2006): Population flactuations of Aphis craccivora and Liriomyza trifolii and their endoparasitoids on certain faba bean varieties. Annals-of-Agricultural-Science-Cairo. 51 (2): 531-540.

Abo Baker, M. A.; S. H. Gad EL-Hak and Y. Y. Abd EL-Aty (1983): Comparative studies of some cultivars of cow pea .Minia J. Res \&Dev.5(12)75-89.

Abou-El-Hagag, G. H. and N. A. Abdel-Hafiz (1999): Seasonal occurrence and relative abundance of the main pests infesting caraway and cumin plants in Upper Egypt. Assiut Journal of Agricultural Sciences. 30 (4): 149-166.

Abou-Fakher, E. M. and N. S. Kawar (1998): Complex of endoparasitoids of aphids (Homoptera, Aphididae) on vegetables and other plants. Entomologicheskoe Obozrenie. 77 (4): 753-763.

Abraham, Verghese; C. M. Kalleshwaraswamy and H. R. A. Kumar (2007): Pests of papaya and their management with special reference to aphid vectors. Acta-Horticulturae. 740: 259-264.

AL-Jibouri, H. A; P. A.; Miller and H. F. Robinson (1958): Genotypic and environmental variance and co variance in an upland cotton stress of interspecific origin. Agron.J.50:633-636. 
Ashraf, M; T. MeNeilly and A. A. BradShow (1987): Selection and heritability of tolerance to sodium chloride in four forages species .Crop Sci. 27:232-234 Attia,

A. A.; A. H. El-Heneidy and E. A. El-Kady (1987): Studies on the aphid, Aphis craccivora, Koch. (Homoptera: Aphididae) in Egypt. Bulletin de la Societe Entomologique d'Egypte. 66: 319-324.

Berta, D. C.; M. V. Colomo and N. E. Ovruski (2002): Interrelations between aphid colonies in tomato and their parasitoid Hymenoptera in Tucuman (Argentina). Boletin de Sanidad Vegetal, Plagas. 28 (1): 67-77.

Boltin, J. (1962):Alfalfa Leonard Hill cond. Inter. Sciences Publishes Ine. New Yourk..

Bredon, R. M.; K .W. Hoker and B.Marshal (1963) : The nutritive value of grasses grown in Uganda when feed to Zebu cattle -the relation between the percentage of crude protein and the other nutrients .J.Agric.Sci.61:101-104.

Burton, G. W. (1952): Quantitative inheritance in grasses .Proc. $6^{\text {th }}$ Int. Grassland Congr., 1: 277-283.

Daterao, S. H.; B. V. Babu. VL. Deshpanda and T. R. Sattiovale (1994): Influences of rhizoium and rhizoium plus molybdenum use efficiency and economy in legumes. Center Demonstration .J.Agric.Sci.Mansura UNi.; 23(3),March 1988.

El-Arnaouty, S. A.; V. Beyssat-Arnaouty; A. Ferran and H. Galal (2000): Introduction and release of the coccinellid Harmonia axyridis Pallas for controlling Aphis craccivora Koch on faba beans in Egypt. EgyptianJournal-of-Biological-Pest-Control. 10 (1/2): 129- 136.

El-Defrawi, G. M.; A. K. Emam; I. A. Marzouk and L. Rizkalla (2000): Population dynamics and seasonal distribution of Aphis craccivora Koch and associated natural enemies in relation to virus disease incidence in faba bean fields. Egyptian Journal of Agricultural Research. 78 (2): 627-641.

El-Desouki, S. A.; F. A. El-Lakwah; A. A. W. Horeya and H. S. Shaalan (2004): Certain aspects on reproductive potential and feeding capacity of two

predators, Coccinella undecimpunctata L. and Chrysoperla carnea (Steph.). Annals-of-Agricultural-Science,-Moshtohor. 42 (4): 2047-2054.

Escechie H. A.; V. Redriguez (1998): Ion compartmentation in salinity stressed of alfalfa seeding growing under different temperature. Communication in soil sci. and Plant analysis .29 (1718) 2607-2618

Gad EL HAk, S. H.; F. I. Mohamed and R. A. Ragab ((1988): An evaluation study of twenty four genotypes of cow pea .Minia J. Agric .Res. \&dev.,10(1):257-268.

Gupta, P. K and J. P. Tewar (2007): Basella rubra L. - additional natural host of cucumber mosaic virus (CMV). Vegetos. 20 (1): 15-18.

Hanson, D. W. and H. F.; Robinson (1956): Statistical genetics and plant breeding Nat .Acad.Sci.,Nat.Res. Council, Washigton, D.C.PP. 164196. 
Hussien H. A. and M. A. Farghali (1998): Genetic and environmental variation, heritability and response to selection in cow pea. Assiut $\mathrm{J}$. Agric.26: 206- 216.

Kumar, R. and R. S. Sangwan (2003): Genetic variability in cow pea .Annalls of Biology v.16(2)181-183.

Lugg- D. G.; A. S. Abdul-Jabbar and H. G. Samisto (1985): Rooting patterns of alfalfa under three irrigation treatment. Proceeding of the $\mathrm{XI}$ international Grass land Congress. August 24-31,Japan , 377-379.

Lumbierres, B.; X. Pons and P. Stary (2005): Parasitoids and predators of aphids associated with public green areas of Lleida (NE Iberian Peninsula). Advances-in-Horticultural-Science. 19 (2): 69-75.

Mandour, N. S.; N. A. S. El-Basha and T. X. Liu (2006): Functional response of the ladybird, Cydonia vicina nilotica to cowpea aphid, Aphis craccivora in the laboratory. Insect-Science. 13 (1): 49-54.

Mchersie B.D. (1994): Environmental stress tolerance in genetically improved plants Agric Food Res. in Ontario 17:2-6

Mendes, S.; M. N. Cervino; V. H. P. Bueno and A. M. Auad (2000): The diversity of aphids and their parasitoids and predators in alfalfa crops. Pesquisa Agropecuaria Brasileira. 35 (7): 1305-1310.

Metwally, S. A. G. (1998): Predators and their role in controlling aphid population. Egyptian Journal of Agricultural Research. 76 (1): 105-116

Mohamed, F. I. (1999): Effect of plant density and foliar nutrition with phosphorus and potassium fertilizer on growth, pod characters green yield and it is components of cow pea .J. Appli. Sci. ;13 (14): 183-194.

Monadjemi, N. (1979): Comparative study of two strains of Aphelinus asychis Walk. (Hym. Aphelinidae) parasitising aphids. Journal of Entomological Society of Iran. 5 (1/2): Pe 35- 38; en 29-31.

Nasser, M. A. K.; S. A. Eraky and M. A. Farghaly (2000): Aphids infesting some cowpea cultivars with relation to their predatory coccinellid in Assiut. Assiut Journal of Agricultural Sciences. 31 (2): 305-316.

Peksen, T. and C. Artik (2004): Comparison of some cow pea genotypes from Turkey for seed yield and yield related characters.J.of Agron.3(2)137-140.

Rakhshani, E.; A.A. Talebi; N. G. Kavallieratos; A. Rezwani; S. Manzari, and A. M.Rayed (2005): Evaluation of some cultivars and mutant of cow pea under Kafer EL-Sheik condition n Msc. Thesis ,Fac. Of Agric., Tanta Uni. $120 \mathrm{pp}$

Rezk, G. N.; A. H. El-Heneidy; A. M. Hekal; S. S. Abdel-Samad (2000): Morphological and biological observations on the aphid parasitoid Lysiphlebus fabarum Marchall (Hymenoptera: Braconidae). Egyptian Journal of Agricultural Research. 78 (3): 1063- 1072.

Selim, A. A.; S. A. El-Refai and A. El-Gantiry (1987): Seasonal fluctuations in the population of Aphis craccivora Koch, Myzus persicae (Sulz),Aphis gossypii (Glov) and their parasites. Annals-of-Agricultural-Science,-AinShams-University. 32 (3): 1837-1848.

Sendecor, G. W. and W.G. Cochran (1968): Statistical Methods ;The Lowa State Univ.Press, Ames Lowa, U.S.A. 
Shantibala, T.; O. Hemchandra and T. K. Singh (2007): Comparative prey consumption and searching efficiency of Coccinella septempunctata Linnaeus on two important pea aphids, Acyrthosiphon pisum (Harris) and Aphis craccivora Ko: Journal-of-Biological-Control. 21(Special):107-111 ch.

Sobba, P. P. and M. Vahaba-Abdul (1998): Genetic variability ,heritability and genetic advance in cow pea .J. of Tropical Agric v36(182) 21-23

Tripathi, R. D.; G. P. Svivastava; M. S. Misra and S. C. C. Pendy (1971): Protein content in some varieties of legumes. The Alla Abad farmer, 16: 291- 294 (C. a. El-Sheik1981) .

Zayed, G. A; and A. M. Mohamed (2003): Genotypes and environmental effects in seven cow pea genotypes under natural infestation by Etilla zinckemlla at two location in southern Egypt. J. Agric Sci. Mansura Univ. 28 (3): 1927- 1936.

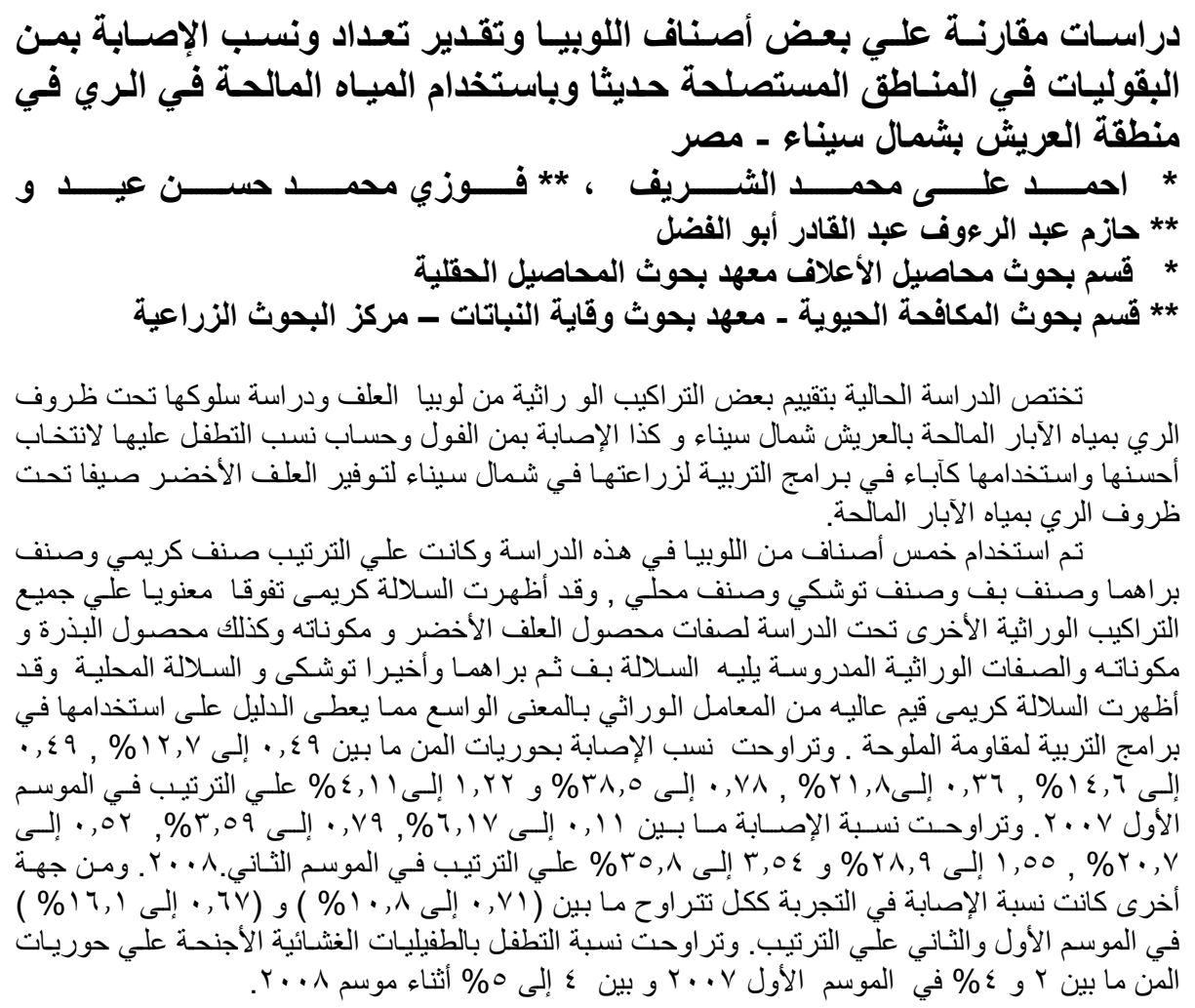



Table (4): Mean performance of the studied characters in 5 cowpea genotypes under salinity condition $2^{\text {nd }}$ cut in the $1^{\text {st }}$ season, North Sinai.

\begin{tabular}{|c|c|c|c|c|c|c|c|c|c|c|c|c|c|c|c|c|}
\hline \multirow{2}{*}{$\begin{array}{l}\text { Characters } \\
\text { Geno }\end{array}$} & \multicolumn{6}{|c|}{ Forage characters } & \multicolumn{3}{|c|}{ Root characters } & \multicolumn{7}{|c|}{ Seed yield characters } \\
\hline & 1 & 2 & 3 & 4 & 5 & 6 & 7 & 8 & 9 & 10 & 11 & 12 & 13 & 14 & 15 & 16 \\
\hline Creamy & 74.8 & 21.5 & 81.45 & 1.33 & 12.4 & 2.24 & 18.5 & 10.0 & 2.01 & 50.70 & 40.69 & 16.0 & 16.0 & 15.8 & 17.2 & 2.52 \\
\hline Buff & 68.3 & 18.4 & 73.58 & 0.93 & 9.9 & 1.57 & 14.5 & 7.0 & 2.49 & 31.90 & 25.05 & 11.0 & 10.0 & 16.0 & 14.6 & 1.36 \\
\hline Barahma & 66.5 & 16.5 & 75.82 & 0.96 & 10.5 & 1.89 & 16.7 & 8.0 & 1.32 & 39.43 & 31.32 & 14.0 & 13.0 & 15.0 & 16.3 & 1.39 \\
\hline Toshki & 61.5 & 13.6 & 62.53 & 0.78 & 7.6 & 1.24 & 12.8 & 9.0 & 2.21 & 26.25 & 20.73 & 8.0 & 8.0 & 11.0 & 12.8 & 0.55 \\
\hline Chick & 51.6 & 10.5 & 58.44 & 0.66 & 4.3 & 0.69 & 11.4 & 5.0 & 2.88 & 13.39 & 10.39 & 5.0 & 4.0 & 8.0 & 11.3 & 0.89 \\
\hline L.S.D. & 5.4 & 1.67 & 4.08 & 0.18 & 1.05 & 0.18 & $2 . .34$ & 2.34 & 0.45 & 3.68 & 2.90 & 3.63 & 0.93 & 3.99 & 1.97 & 8.78 \\
\hline \multicolumn{17}{|c|}{$2^{\text {nd }}$ cut in the $2^{\text {nd }}$ season } \\
\hline Creamy & 75.50 & 22.7 & 83.50 & 1.41 & 13.20 & 2.42 & 20.5 & 13.0 & 1.45 & 55.16 & 52.94 & 20.5 & 18.0 & 18.0 & 17.2 & 2.47 \\
\hline Buff & 66.50 & 19.6 & 74.80 & 0.96 & 10.30 & 1.72 & 16.4 & 11.0 & 2.26 & 36.46 & 34.99 & 16.2 & 15.3 & 19.0 & 15.2 & 1.28 \\
\hline Barahma & 71.60 & 18.3 & 77.40 & 1.12 & 10.80 & 1.89 & 18.5 & 12.0 & 2.48 & 41.24 & 39.57 & 14.5 & 13.3 & 17.0 & 16.5 & 1.32 \\
\hline Toshki & 63.50 & 14.8 & 66.40 & 0.82 & 8.50 & 1.41 & 14.6 & 11.0 & 1.96 & 30.10 & 28.89 & 8.5 & 6.8 & 13.0 & 10.6 & 0.48 \\
\hline Chick & 54.20 & 12.2 & 60.30 & 0.71 & 4.80 & 0.79 & 12.8 & 8.0 & 2.07 & 15.71 & 15.08 & 6.3 & 4.0 & 10.0 & 7.5 & 0.94 \\
\hline L.S.D. & 4.54 & 8.83 & 4.36 & 0.25 & 1.38 & 0.24 & 2.22 & 2.52 & 0.11 & 5.14 & 4.93 & 2.94 & 1.97 & 3.23 & 2.04 & 4.87 \\
\hline \multicolumn{17}{|c|}{ The average of the $2^{\text {nd }}$ cut in $1^{\text {st }}$ and $2^{\text {nd }}$ seasons } \\
\hline Creamy & 75.15 & 22.1 & 82.48 & 1.37 & 12.78 & 2.37 & 19.6 & 11.5 & 1.39 & 52.93 & 46.81 & 17.10 & 16.5 & \begin{tabular}{|l|l|}
16.83 \\
\end{tabular} & 17.20 & 2.496 \\
\hline Buff & 67.40 & 19.0 & 74.19 & 0.95 & 9.9 & 1.65 & 15.4 & 9.0 & 2.38 & 34.19 & 30.02 & 13.6 & 12.63 & \begin{tabular}{|l|}
17.50 \\
\end{tabular} & 14.90 & 1.320 \\
\hline Barahma & 69.05 & 17.4 & 76.61 & 1.04 & 10.67 & 1.86 & 17.6 & 10.0 & 2.14 & 40.33 & 35.45 & 14.29 & 13.13 & \begin{tabular}{|l|}
16.00 \\
\end{tabular} & 16.40 & 1.356 \\
\hline Toshki & 62.70 & 14.2 & 64.47 & 0.80 & 8.03 & 1.33 & 13.7 & 10.0 & 1.98 & 28.17 & 24.83 & 8.25 & 7.38 & \begin{tabular}{|l|}
12.00 \\
\end{tabular} & 11.70 & 0.469 \\
\hline Chick & 52.82 & 11.4 & 59.37 & 0.69 & 4.53 & 0.74 & 12.1 & 6.50 & 2.68 & 14.56 & 12.74 & 5.65 & 4.00 & 9.00 & 9.470 & 0.910 \\
\hline L.S.D. & 3.12 & 1.72 & 2.87 & 0.18 & 0.78 & 0.17 & 1.67 & 1.93 & 0.19 & 9.99 & 2.51 & 2.08 & 1.20 & 2.69 & 1.50 & 4.84 \\
\hline
\end{tabular}

